\title{
Phylogenetic Relationships of the Canary Islands Endemic Lizard Genus Gallotia (Sauria: Lacertidae), Inferred from Mitochondrial DNA Sequences
}

\author{
Pedro González, Francisco Pinto, Manuel Nogales,* José J iménez-asensio, Mariano Hernández, \\ AND Vicente M. CABRERA
}

Department of Genetics and * Department of Zoology, University of La Laguna, Tenerife, Canary Islands, Spain

Received June 22, 1995; revised September 18, 1995

Phylogenetic relationships among species and subspecies of the Canary I sland endemic lizard genus Gallotia are inferred based on nucleotide sequences of fragments of 125 ribosomal RNA and cytochrome $b$ mitochondrial genes. The four morphologically established species have also been recognized at the molecular level. Relative affinities among species follow an eastern-western geographic transect. The nearly extinct species Gallotia simonyi from the most western island of EI Hierro is closely related to the common western species Gal lotia gall oti, the nearest branch to this pair is Gallotia stehlini from the central island of Gran Canaria, and finally, Gallotia atlantica from the two eastern and geologically oldest islands appears as the most distantly related species of the group. At the statistical level, four subspecies can be recognized in G. galloti, but only two in G. atlantica. ๑ 1996 Academic Press, Inc.

\section{INTRODUCTION}

Lacertids are represented in the Canary Islands by the endemic genus Gallotia (Arnold, 1973). As all the Canary Islands are of independent volcanic origin the speciation process of the genus is of great taxonomic and evolutionary interest and has been the object of numerous studies since the beginning of the last century (for a review see Machado et al., 1985). Different morphological analyses agree in recognizing four Gallotia species with different distributions in the seven main islands of the Archipelago (Klemmer, 1976; Arnold, 1989): Gall otia atlantica inhabiting the eastern islands of Lanzarote and Fuerteventura and their coastal islets, Gallotia stehlini endemic to the central island of Gran Canaria, Gallotia galloti present in the western islands of Tenerife, La Gomera, La Palma, and EI Hierro, and Gallotia simonyi, a species in danger of extinction, with a small known population on an almost inaccessible cliff in Hierro (Böhme and Bings, 1975). Reports of the presence of small populations of $G$. atlantica on Gran Canaria (Barquín and Martín, 1982) and of G. stehlini on Fuerteventura (Naranjo et al., 1991) pose the question of the time of these colonizations and their degree of differentiation. Alternative phylogenetic relationships among the species have been proposed, with $\mathrm{G}$. stehlini and $\mathrm{G}$. simonyi being the closest related species (Arnold, 1989), G. galloti and G. stehlini as sister taxa, and G. atlantica less closely related (Thorpe et al., 1985), G. stehlini being the most divergent species and G. gall oti and G. simonyi the most related ones (Mayer and Bishoff, 1991), G. gall oti and G. atlantica being sister species, and G. stehlini more divergent (Thorpe et al., 1993a, 1994). Even more confusion exists at the subspecies level. For G. atlantica some authors recognize two subspecies, G. a. atlantica in Lanzarote and its islets and G. a. mahorataein Fuerteventura and Lobos islet (Bischoff, 1985). Others claim four subspecies, G. a. atlantica inhabiting the main Lanzarote and Fuerteventura islands and Lobos, Graciosa, and Montaña Clara islets, G. a. delibesi for the small southeast Gran Canaria population, G. a. lauraeonly found in a vol canic badland named Malpaís de la Corona in the northeast of Lanzarote, and G. a. ibagnezi endemic to the Alegranza islet (Castroviejo et al., 1985). Similar discrepancies exist to explain the radiation process of the species $\mathrm{G}$. galloti. Morphological studies have recognized up to five subspecies, one for each main western island, El Hierro, La Gomera, La Palma, and two for Tenerife (Boettger and Müller, 1914; Bischoff, 1982). Recently, another subspecies, G. g. insulanagae, has been proposed for the Tenerife Roque de Fuera islet population (Martín, 1985). However, at the molecular level Thorpe et al. (1993b) suggested only two subspecific lineages in this species, one named Northern made up of La Palma, north Tenerife, and south Tenerife populations, and a Southern one including those of Gomera and Hierro.

With the aim of constrasting the mainly morphologi- 


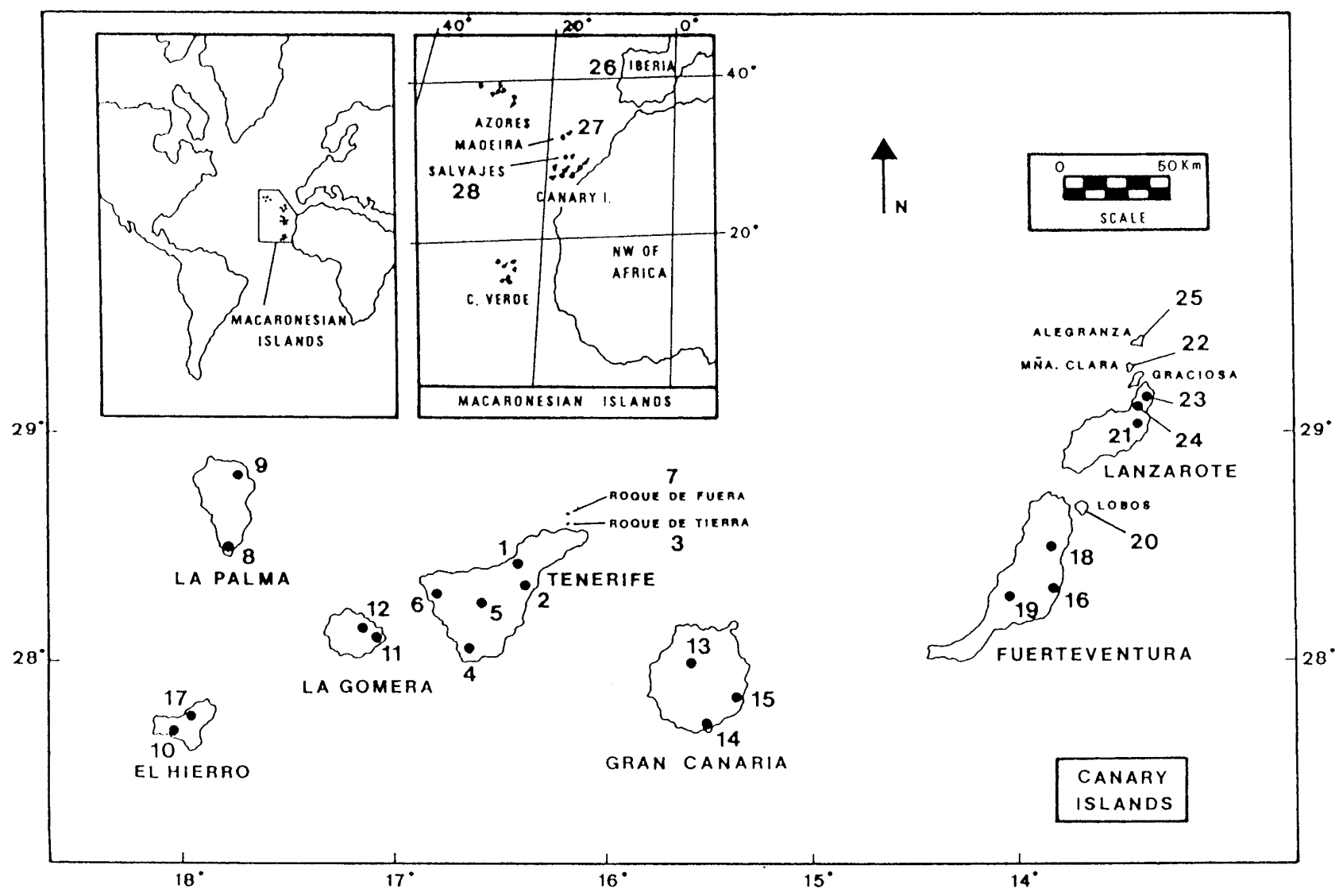

FIG. 1. Distribution of the endemic lizards (genus Gallotia) of the Canary I slands and the outgroup lizards (genera Lacerta and Podarcis) analyzed in the present study. Numbers of the localities correspond with numbers in Table 1.

cal phylogenies proposed for Gallotia with one based on molecular characters, we have studied representatives of each recognized taxon at the mitochondrial DNA level. Sequences with different evolving rates and taxonomic utility (Kocher et al., 1989) have been used to detect inter-and intraspecific differentiation without the strong influence of adaptive convergence often encountered with morphological data.

\section{MATERIALS AND METHODS}

\section{Specimens Analyzed}

The geographic origin of the studied specimens is shown in Fig. 1. Specimens were captured in the field (w) or obtained from collection material kept in $70 \%$ ethanol (c). In both cases a piece of the tail approximately $0.5 \mathrm{~g}$ in weight was clipped off; after that live animals were released in the same capture place. Table 1 shows the number of samples and locality of capture for each Gallotia species and their putative subspecies. Lacerta Iepida and Podarcis dugesii were included as outgroup genera. Both subspecies proposed for $\mathrm{P}$. dugesii (Bischoff et al., 1989) were also examined.

\section{DNA Extraction}

Before treatment, alcohol samples were washed 30 min in $50 \mathrm{ml}$ sterile distilled water. Total DNA was isolated from $0.1 \mathrm{~g}$ of tail tissue, homogenized in $500 \mu \mathrm{l}$ of lysis buffer $(50 \mathrm{~mm} \mathrm{KCl}, 2.5 \mathrm{~mm} \mathrm{Cl} 2 \mathrm{Mg}, 0.45 \%$ Nonidet $\mathrm{P}-40,0.45 \%$ Tween $20,10 \mathrm{~mm}$ Tris- $\mathrm{HCl}, \mathrm{pH} 8.0$ ). To this homogenate, $10 \mu \mathrm{l}$ of $20 \%$ SDS and $10 \mu \mathrm{l}$ Proteinase $\mathrm{K}(20 \mathrm{mg} / \mathrm{ml})$ were added, and the mixture was incubated $4 \mathrm{~h}$ at $55^{\circ} \mathrm{C}$ with occasional agitation. Proteins were removed by consecutive phenol, phenol-chloroform, chloroform, and ether extractions. The aqueous phase containing total DNA was boiled $5 \mathrm{~min}$ and $5 \mu \mathrm{l}$ was used as a template for the polymerase chain reaction (PCR) amplification.

\section{DNA Amplification and Sequencing}

Two segments of the mitochondrial genome were amplified: a 307-bp regi on of the cytochrome b (cytb) gene, corresponding to sites 14842 to 15148 in humans (Anderson et al., 1981), and an approximately 400-bp re gion of the 12S rRNA gene, corresponding to sites 1092 to 1477 in humans. Primers were the sameas in Kocher et al. (1989). Amplifications were carried out in 100- $\mu$ l volumes, and Taq polymerase and amplification buffer 


\section{TABLE 1}

\section{List of Specimens Examined in the Present Study}

Species/subspecies

Abreviations

Source

Locality $^{b}$

Gallotia g. eisentrauti Ggae-1

Ggae-2

Ggae-3

Gallotia g. galloti

Ggag-1

Ggag-2

Ggag-3

Gallotia g. insulanagae Ggai-1

Gallotia g. palmae

Ggap-1

Ggap-2

Ggap-3

Gallotia g. caesaris Ggac-1

Gallotia g. gomerae Ggago-1

Ggago-2

Gallotia stehlini

Gst-1

Gst-2

Gst-3

Gst-4

Gallotia simonyi

Gsis-1

Gsis-2

Gsis-3

Gallotia a. atlantica Gata-1

Gata-2

Gata-3

Gata-4

Gata-5

Gata-6

Gata-7

Gata-8

Gallotia a. Iaurae

Gatl-1

Gatl-2

Gallotia a. ibagnezi Gati-1

Gallotia a. delibesi Gatd-1

Lacerta lepida Lle-1

Podarcis d. dugesii Pdud-1

Podarcis d. selvagensis Pdus-1

w El Sauzal (Tenerife) [1]

w Arafo (Tenerife) [2]

C Roque de Tierra (Tenerife) [3]

w El Palmar (Tenerife) [4]

C Las Cañadas (Tenerife) [5]

w Masca (Tenerife) [6]

c Roque de Fuera (Tenerife) [7]

c Fuencaliente (La Palma) [8]

C Los Sauces (La Palma) [9]

w Los Sauces (La Palma) [9]

c El J úlan (EI Hierro) [10]

w San Sebastián (La Gomera)

[11]

c Hermigua (La Gomera) [12]

w J uncalillo (Gran Canaria) [13]

w Maspalomas (Gran Canaria)

[14]

C Arinaga (Gran Canaria) [15]

w B la Torre (Fuerteventura) [16]

c Fuga de Gorreta (EI Hierro) [17]

c Fuga de Gorreta (EI Hierro) [17]

c Fuga de Gorreta (EI Hierro) [17]
W

W

C

W

w

C

C

C

C

C

c

c

C

w

c
La Asomada (Fuerteventura) [18]

La Asomada (Fuerteventura) [18]

Pájara (Fuerteventura) [19]

Lobos Islet [20]

Lobos Islet [20]

Guatiza (Lanzarote) [21]

Montaña Clara (Lanzarote) [22]

Montaña Clara (Lanzarote) [22]

Los J ameos (Lanzarote) [23]

Haría (Lanzarote) [24]

Alegranza (Lanzarote) [25]

Arinaga (Gran Canaria) [15]

Badajoz [26]

Madeira [27]

Salvaje Grande [28]
${ }^{a}$ w, wild; c, collection.

b Numbers in brackets correspond with numbers in Fig. 1. were the standard ones from Promega. Cycle profile for the cytb region was: $1 \mathrm{~min}$ at $94^{\circ} \mathrm{C}, 1 \mathrm{~min}$ at $55^{\circ} \mathrm{C}$, and $1 \mathrm{~min}$ at $72^{\circ} \mathrm{C}$, for 35 cycles, and for $12 \mathrm{~S}$ rRNA: $1 \mathrm{~min}$ at $94^{\circ} \mathrm{C}, 1 \mathrm{~min}$ at $50^{\circ} \mathrm{C}$, and $1 \mathrm{~min}$ at $72^{\circ} \mathrm{C}$, for 35 cycles. After precipitation with $0.6 \mathrm{vol}$ polyethylene glycol/ $\mathrm{NaCl}(20 \%$ wt/vol PEG 6000, $2.5 \mathrm{~m} \mathrm{NaCl})$ the amplified products were directly cycle sequenced using the fmol DNA sequencing system (Promega). In each case, both complementary strands were sequenced with the same primers as in the amplification process but in separate reactions. In all cases PCR specifications were: $1 \mathrm{~min}$ at $94^{\circ} \mathrm{C}, 1 \mathrm{~min}$ at $58^{\circ} \mathrm{C}$, and $1 \mathrm{~min}$ at $72^{\circ} \mathrm{C}$, for $35 \mathrm{cycles}$.

\section{Sequence Analysis}

Nucleotide sequences were aligned using the CLUSTAL V program (Higgins et al., 1992). Following Hedges et al. (1991) every length difference of one or more bases was scored as a single mutational event. To accomplish this, the difference matrix based on the aligned sequences was modified in such a way that in all pairs of comparisons each indel was considered as a single transitional difference. Sequence divergence between taxa for cytb and 12S rRNA were cal culated by the Kimura's (1980) two-parameter method using the MEGA 1.01 program (Kumar et al., 1993). A combined analysis of cytb and 12S rRNA was not carried out because not all the specimens had been analyzed for both sequences. Phylogenies were constructed assuming constant (UPGMA; Sneath and Sokal, 1973) and variable (NJ ; Saitou and Nei, 1987) evolutionary rates, also using the MEGA 1.01 program. Confidence in the tree topologies was evaluated by computing the standard errors of branching points in the UPGMA tree (Nei et al., 1985) using the J in and Ferguson (1990) program and by the bootstrap method with 2000 iterations in the NJ tree (Felsenstein, 1985) using the MEGA 1.01 program.

\section{RESULTS}

Amplified DNA from fresh and collection material gave sequences in agreement with taxonomic assignments irrespective of their origin. In spite of several attempts under different conditions we were unable to amplify collection specimens Ggago-2 and Gatl-1 for 12S rRNA and Ggag-2, Ggai-1, Ggae-3, Gata-3, and Gatl-2 for cytb.

F or cytb sequence no indels were observed, and 118 of the 307 positions were variable among 30 different sequences (Fig. 2). Most (73.7\%) substitutions occurred in third base codon positions. Only 30 substitutions gave amino acid replacements (Fig. 3) and 15 of them were not conservative. The two histidines involved in hemeligation (Howell and Gilbert, 1988) areamong the invariant amino acids.

The size of the 12S rRNA fragment ranges from 389 bp for some G. atlantica specimens to 393 bp for the 
1111111111111111111111111111111111222222222222222222222222222222222222233333 11112222333333444445555566677777888889900001112223333344445566667778999999000111222222333334455555666677888999000000 4734692458013489013690256814702369234584713462581480367925891403690587012369589134013679123451703679258914036925812347 Ggag-1 CACCGATGCA TTTCATCATA CCACTGAACC ACACCAACCC AACGCTTTCC CCCATGCATA CCTACACTTC CATACTACCA ACCTACTATT ACTCCCAACT TCATACCATC ACTTCTTA

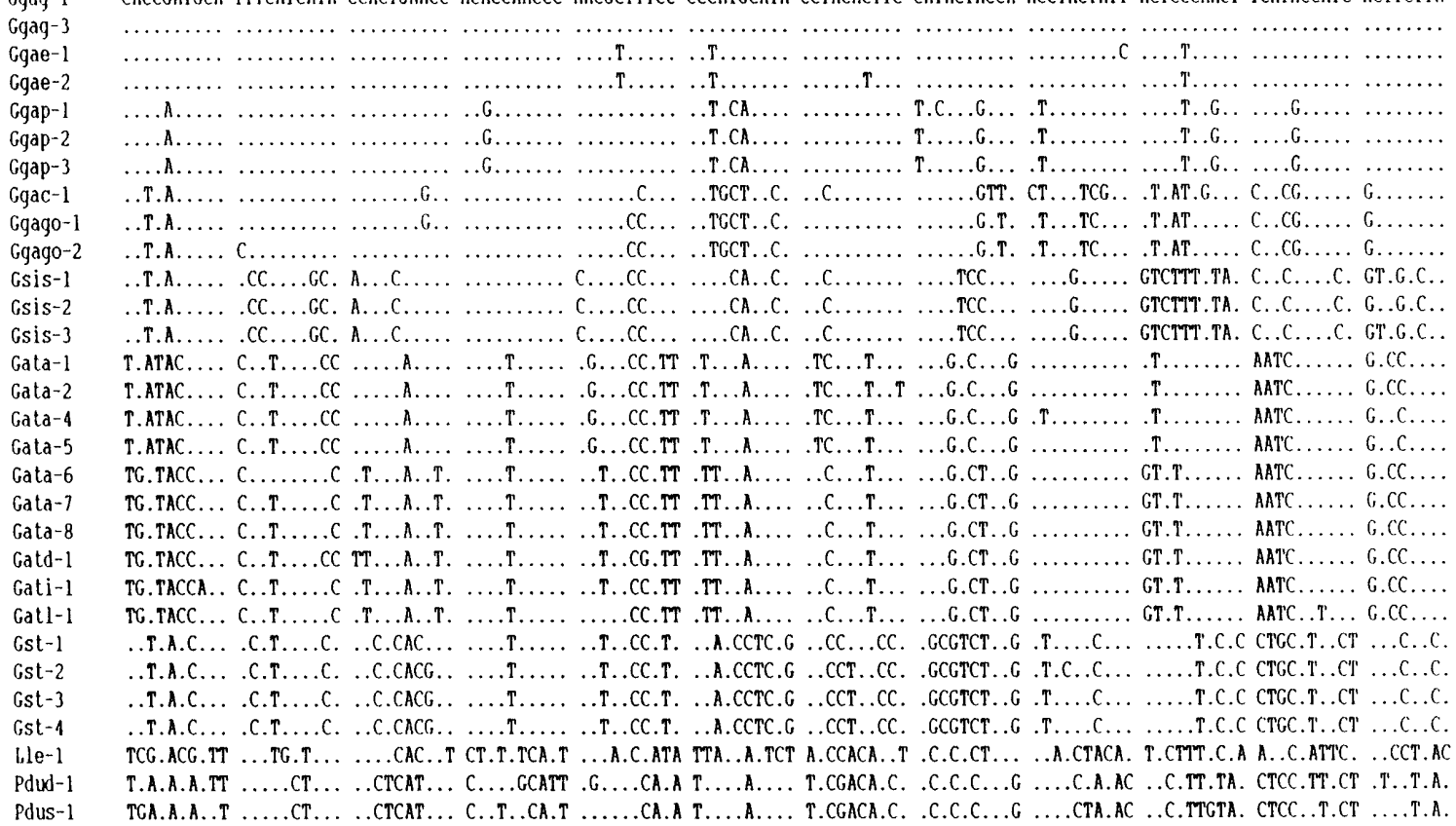

FIG. 2. Cytb nucleotide differences among the 30 specimens studied. Site 4 corresponds with position 14,845 in the published human reference sequence (Anderson et al., 1991).

species G. galloti and P. dugesii due to small indels of 1-3 bp. Intraspecific size polymorphism was only detected in G. atlantica and P. dugesii (Fig. 4). In addition, 97 of 396 positions were variable among 33 different sequences ( $\mathrm{Fig.} \mathrm{4).}$

As customary in studies of animal mtDNA, there is a pronounced transition bias in both sequences, particularly within subspecies. Transition-transversion ratios decline with increasing sequence divergence (Table 2).

Significant differences in sequence divergence were found between thetwo regions studied here. The cytb is 3 times more variable than 12S rRNA at the subspecies level, 2-fold at species level, but only 1.2 when genera are compared (Table 3).

The UPGMA and NJ analyses of the cytb data produced essentially identical topologies (Figs. 5A and 5B), as did those for the $12 \mathrm{~S}$ rRNA data (Figs. 5C and 5D). The possible effects that rRNA secondary structure could have in these analyses have not been taken into account (see also Hedges et al., 1991). As a consequence of their different variability, each fragment provides information for taxa at different levels. Subspecies branches were only significantly detected in the cytb analyses, whereas the species relationships were better inferred from the $12 \mathrm{~S}$ rRNA, likely as the result of greater saturation evident in the cytb sequences.

\section{DISCUSSION}

The average sequence divergence among the Lacertidae genera studied here for cytb $(0.245 \pm 0.025)$ and $12 S$ rRNA $(0.195 \pm 0.010)$ are within the ranges observed for other lizards (Hedges et al., 1991) and fish genera (Zhu et al., 1994). From UPGMA and NJ analyses the Canary I slands endemic genus Gall otia appears as a monophyletic group (Fig. 5) as was al ready proposed based on morphological (Arnold, 1973) and karyological analyses (Cano et al., 1984; López-J urado et al., 1986).

Affinities among species follow an eastern-western geographic transect. The nearly extinct species G. simonyi, from the most western island of El Hierro, appears as a sister species of $\mathrm{G}$. gall loti with a genetic distance for cytb of only $0.122 \pm 0.008$. Furthermore, in the $12 \mathrm{~S}$ rRNA topologies $\mathrm{G}$. simonyi clusters within the G. gall oti complex, being more closely related to the Tenerife and La Palma subspecies than to its sympatric subspecies from El Hierro (Fig. 5). These molecular data do not support the ol dest taxonomic classification that considered G. simonyi simonyi and G. simonyi stehlini as races of a single polytypic species (Steindachner, 1889; Schenkel, 1901). Neither do they support the more recent idea (Arnold, 1989) that has considered G. simonyi and G. stehlini as the most closely related species of the genus. Our data are, however, in 
$\begin{array}{llllllllllllllllllll}1 & 1 & 1 & 1 & 2 & 2 & 3 & 3 & 3 & 4 & 5 & 5 & 6 & 7 & 7 & 7 & 7 & 7 & 8 & 0\end{array}$

$\begin{array}{lllllllllllllllllllll}8 & 0 & 1 & 3 & 4 & 4 & 8 & 4 & 5 & 8 & 3 & 0 & 7 & 4 & 1 & 4 & 6 & 7 & 8 & 6 & 1\end{array}$

Ggag-1 C I I I I N N I A H H I L M Y S L $F$ T L L

Ggap-1 . . . . . . . . . . . . T . . . . .

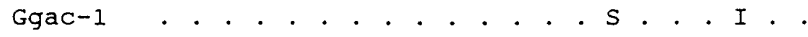

Ggago-1 . . . . . . . . . . . . . . . . . I .

Ggago-2 . T. . . . . . . . . . . . . I. .

Gsis-1 . . T. V . . . . . . . . . V I P

Gsis-2 . . T. V . . . . . . . . . V I P

Gsis-3 . . T V . . . . . . . . . VI P

Gata-1 . T. . . . V . . . . . . I. .

Gata-2 . T. . . . V . . . . . . I .

Gata-4 . T. . . . V . . . . . . I .

Gata-5 . T. . . V . . . . . . I. .

Gata-6 . T. . . . . . . . . . . V .

Gata-7 . T. . . . . . . . . . . V.

Gata-8 . T . . . . . . . . . . V .

Gatd-1 . T. . . . . Q . . . . . V .

Gati-1 Y $Y$. . . . . . . . . . . V .

Gatl-1 . T. . . . . . . . . . . . V. .

Gst-1

Gst-2

Gst-3

Gst-4

Pdud-1

Pdus -1

Lle-1

FIG. 3. Cytb amino acid differences among the 30 specimens studied. Sites correspond with the published human reference peptide sequence (Anderson et al., 1991).

agreement with previous molecular results based on albumin immunological analyses (Mayer and Bischoff, 1991).

Less clear is the relative proximity of the three welldefined species, G. atlantica, G. stehlini, and G. galloti. Each mtDNA region supports a different clustering of these species. The cytb data set presents G. atlantica and G. galloti as the more related species with $67 \%$ of bootstrap support on the NJ tree (Fig. 5B). The same relative positions hold for the UPGMA tree, but standard errors on nodes overlap (Fig. 5A). Conversely, in the 12S rRNA analyses $G$. atlantica significantly branches off before the G. galloti-G. stehlini pair in both trees (Figs. 5C and 5D). In order to avoid saturation problems due to the faster divergence rate of cytb compared to 125 rRNA, we reanalyzed cytb at the amino acid level, and al so taking into account only first and second codon positions (data not shown). The topol- ogy in these trees was similar tothat obtained with $12 \mathrm{~S}$ rRNA sequences but without statistical significance. Therefore G. galloti and G. stehlini appear to be sister taxa, with $\mathrm{G}$. atlantica more distantly related to them. This is not in agreement with previous molecular results based on al bumin immunological analyses (Mayer and Bischoff, 1991), mtDNA restriction fragment polymorphism (Thorpe et al., 1993a), mtDNA sequences, and nuclear RAPD analyses (Thorpe et al., 1994) but does agree with the interspecific relationships found in earlier morphological numerical analyses (Thorpe et al., 1985; Arnold, 1989).

Intraspecific differentiation is only detected with the cytb data set. For the species G. galloti, up to four of the six morphologically recognized subspecies can be also distinguished at the mol ecular level; G. g. gomerae in La Gomera, G. g. caesaris in EI Hierro, G. g. palmae in La Palma, and G. g. galloti in Tenerife (Figs. 5A and 5B). In accordance with the radiation of the species proposed in previous molecular studies by Thorpe et al. (1993ab), G. galloti specimens from Tenerife cluster first with those of La Palma and are well differentiated from those of La Gomera and EI Hierro (Figs. 5A and 5B). The subspeciation within Tenerife proposed by Bischoff (1982), with G. g. galloti from southern and central parts of the I sland and G. g. eisentrauti from the Anaga peninsula and the majority of the North coast, is not statistically supported in the UPGMA tree (Fig. 5A). However, it deserves mention that specimens morphologically classified as G. g. galloti (Ggag-1 and Ggag-3) cluster together in $89 \%$ of the cases in the bootstrap analyses, and those recognized as G. g. eisentrauti (Ggae-1 and Ggae-2) did so in 85\% (Fig. 5B). Apparently, analyses including larger numbers of specimens and/or the most variable mtDNA regions will be necessary in order to distinguish these morphological levels of differentiation.

Morphologically, the intraspecific variation of $\mathrm{G}$. atlantica is not as obvious as with G. galloti (Thorpe, 1985). This fact is corroborated, at the molecular level, by the average values of their intraspecific distances (3.06 and 5.57\%, respectively). On the phylogenetic trees only two clusters of $\mathrm{G}$. atlantica specimens can be distinguished, those bel onging to the Lanzarote island and surrounding islets and those from F uerteventura and Lobos (Figs. 5A and 5B). These results are fully consistent with the classification proposed by Bischoff (1982) based on the variability of several biometric characters: one subspecies, G. a. atlantica, for the Lanzarote cluster and one subspecies, G. a. mahoratae, for Fuerteventura. This classification is in disagreement with that of Castroviejo et al. (1985). Although Gran Canaria has a greater geographic distance from Lanzarote than from Fuerteventura, the representative specimen of the $G$. atlantica population found on the Gran Canaria island (Gatd-1) belongs to the Lanzarote subspecies G. g. atlantica (Figs. 5A and 5B), 
1111111111111111111111111122222222222222222222222222222222222333333333333333333333333333

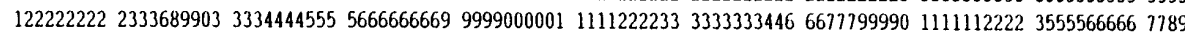
91012345678569961701369126712341234567801234015890138902580123456782638901456786045678578984579156780110

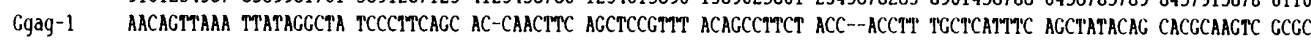

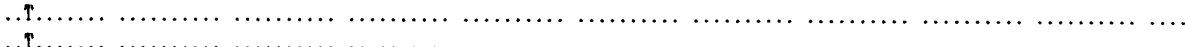

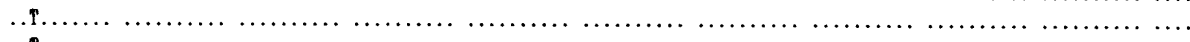

. T. .

.. T.

. $1 \ldots \ldots$

r...................

. $1 \ldots \ldots . . . .$.

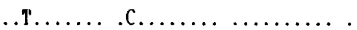

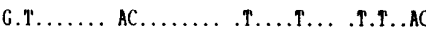

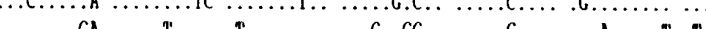

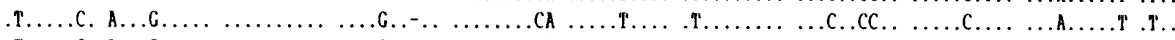

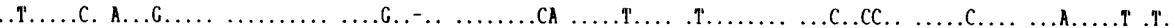

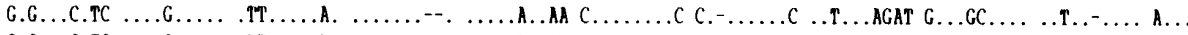

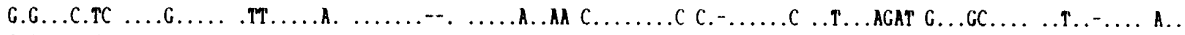

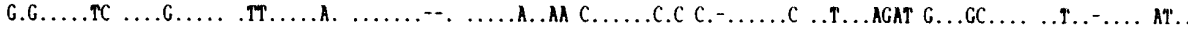

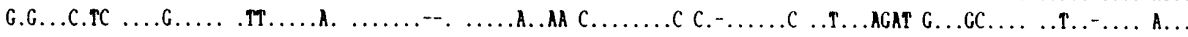

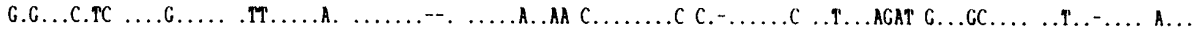

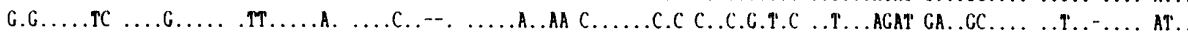

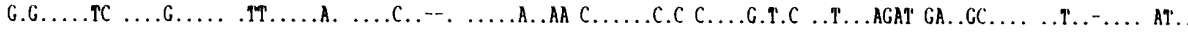

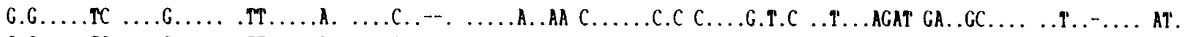

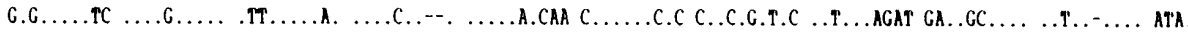

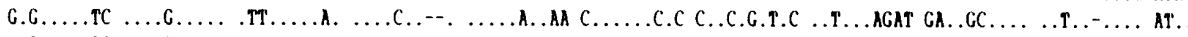

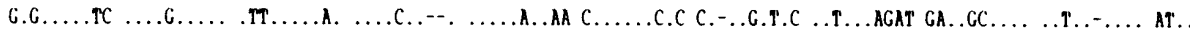

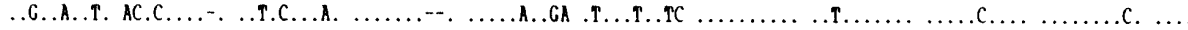

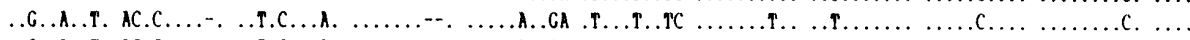

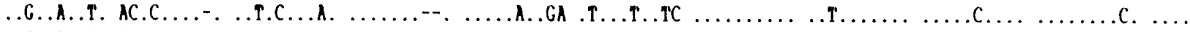

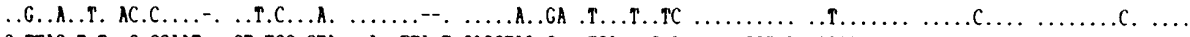

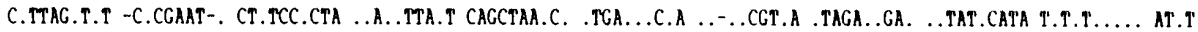
.TA-AGCT.T C.G.TA.T-G . .T.CCGCCA GA.T. .AA. . . FCTAACCC ..GAT..C.C C..CC. .TAA CTGGA. .CAT ...AC.C.T. ..TAT.TA.T AT.T Pdus-1 .TA-AGCT.T C.G.TA.T-C ..T.CCGCCA GA.T. .AA. . . TCTAACCC ..CAT.C. . C. . ...TAA CCGGA. .GAT G. .AC.C.T. . I'AT. IA.T AT.T

FIG. 4. $12 \mathrm{~S}$ rRNA nucleotide differences among the 33 specimens studied. Site 9 corresponds with position 1100 in the published human reference sequence (Anderson et al., 1991).

\section{TABLE 2}

\section{Transitions (Ts), Transversions (Tv), and Ts/Tv Ratios within Subspecies and between Subspecies, Species, and Genera}

\begin{tabular}{lccc} 
& \multicolumn{2}{c}{ cytb } & \\
\cline { 2 - 3 } & $\begin{array}{c}\text { Total } \\
\text { sequence }\end{array}$ & $\begin{array}{c}\text { Third } \\
\text { position }\end{array}$ & 12S rRNA \\
\hline Within subspecies & & & \\
N & 40 & 40 & 58 \\
Ts \pm SE & $1.98 \pm 0.95$ & $1.48 \pm 1.24$ & $0.83 \pm 0.99$ \\
Tv \pm SE & $0.13 \pm 0.33$ & $0.13 \pm 0.33$ & 0.00 \\
Ts/Tv & 15.23 & 11.38 & \\
Between subspecies & & & \\
N & 60 & 60 & 73 \\
Ts \pm SE & $14.37 \pm 4.20$ & $10.92 \pm 2.94$ & $7.64 \pm 4.48$ \\
Tv \pm SE & $1.72 \pm 1.01$ & $1.57 \pm 0.95$ & $1.23 \pm 1.17$ \\
Ts/Tv & 8.35 & 6.96 & 6.21 \\
Between species & & & \\
N & 252 & 252 & 305 \\
Ts \pm SE & $33.76 \pm 4.64$ & $25.44 \pm 4.74$ & $20.18 \pm 4.15$ \\
Tv \pm SE & $8.60 \pm 2.52$ & $8.25 \pm 2.51$ & $9.13 \pm 2.94$ \\
Ts/TV & 3.93 & 3.08 & 2.21 \\
Between genera & & & \\
N & 83 & 83 & 92 \\
Ts \pm SE & $35.33 \pm 3.56$ & $27.29 \pm 3.36$ & $38.15 \pm 1.82$ \\
Tv \pm SE & $27.78 \pm 5.94$ & $20.20 \pm 4.85$ & $28.28 \pm 2.10$ \\
Ts/Tv & 1.27 & 1.35 & 1.35 \\
\hline
\end{tabular}

with a mean divergence from these specimens of only $0.5 \%$, whereas the mean distance from those of Fuerteventura is $4.6 \%$. The colonization of Fuerteventura by $\mathrm{G}$. stehlini seems to be more recent as the Fuerteventura representative (Gst-4) is identical to the Gst3 specimen from Gran Canaria. Finally, the subspeciation proposed by Bischoff et al. (1989) for the outgroup species of this study, P. dugesii, for the populations from Madeira ( $P$. dugesii dugesii) and Salvajes islands ( $P$. dugesii selvagensis) is sound at the molecular level (Figs. 5A and 5B).

\section{Sequence and Sample Availability}

The nucleotide sequences in this paper are available from the GenBank/EMBL databases and are as fol-

\section{TABLE 3}

\section{Mean Distances within and between Subspecies and between Species and Genera}

\begin{tabular}{lrrrrr}
\hline & \multicolumn{2}{c}{ Cytb } & & \multicolumn{2}{c}{ 12S rRNA } \\
\cline { 2 - 3 } \cline { 6 - 7 } & $\mathrm{N}$ & $\mathrm{d} \pm \mathrm{SE}$ & & $\mathrm{N}$ & $\mathrm{d} \pm \mathrm{SE}$ \\
\hline Within subspecies & 40 & $.006 \pm .004$ & & 58 & $.002 \pm .003$ \\
Between subspecies & 60 & $.055 \pm .018$ & & 73 & $.023 \pm .015$ \\
Between species & 252 & $.157 \pm .024$ & & 305 & $.079 \pm .018$ \\
Between genera & 83 & $.244 \pm .025$ & & 92 & $.193 \pm .010$ \\
\hline
\end{tabular}



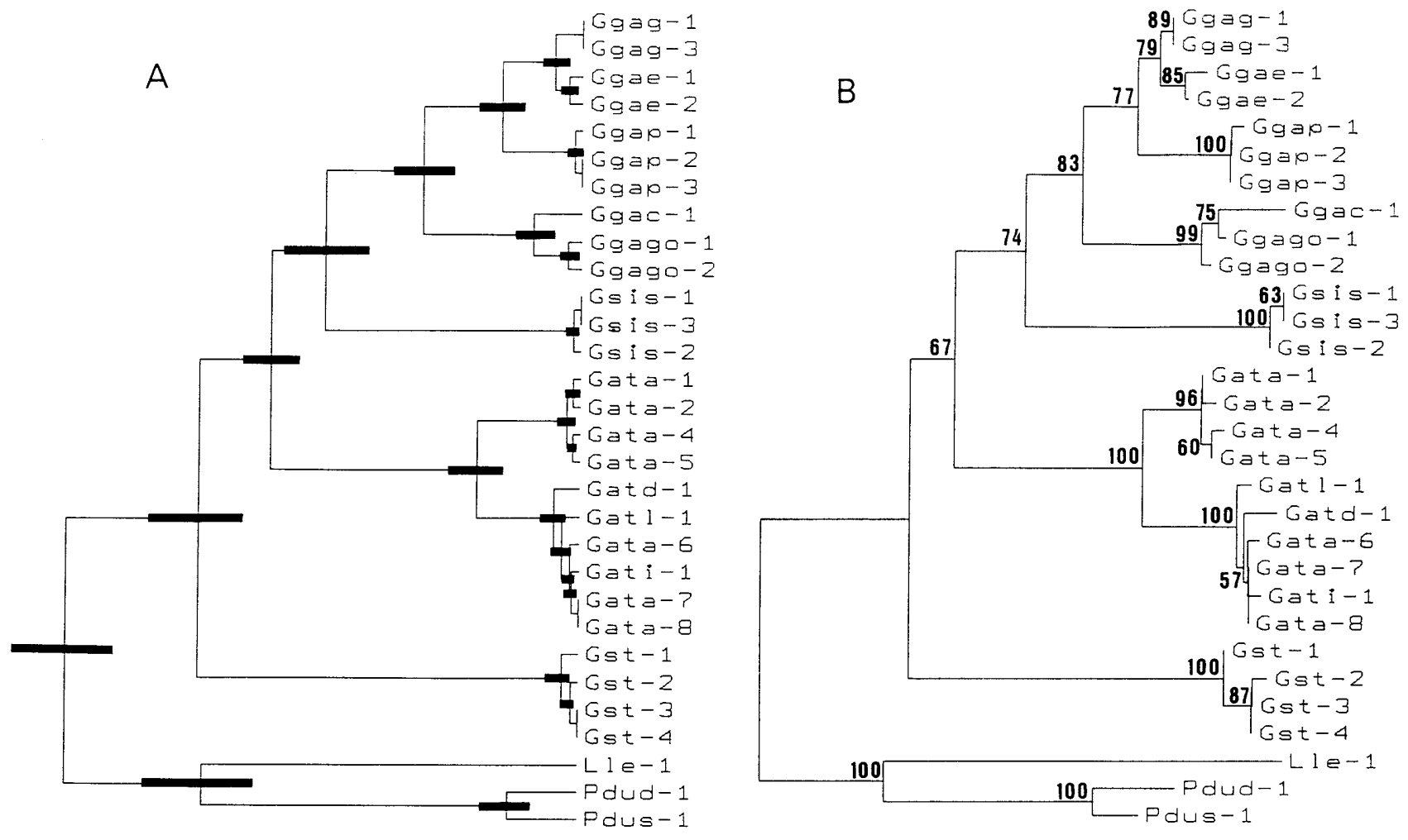

$\theta \quad 01$

0.01
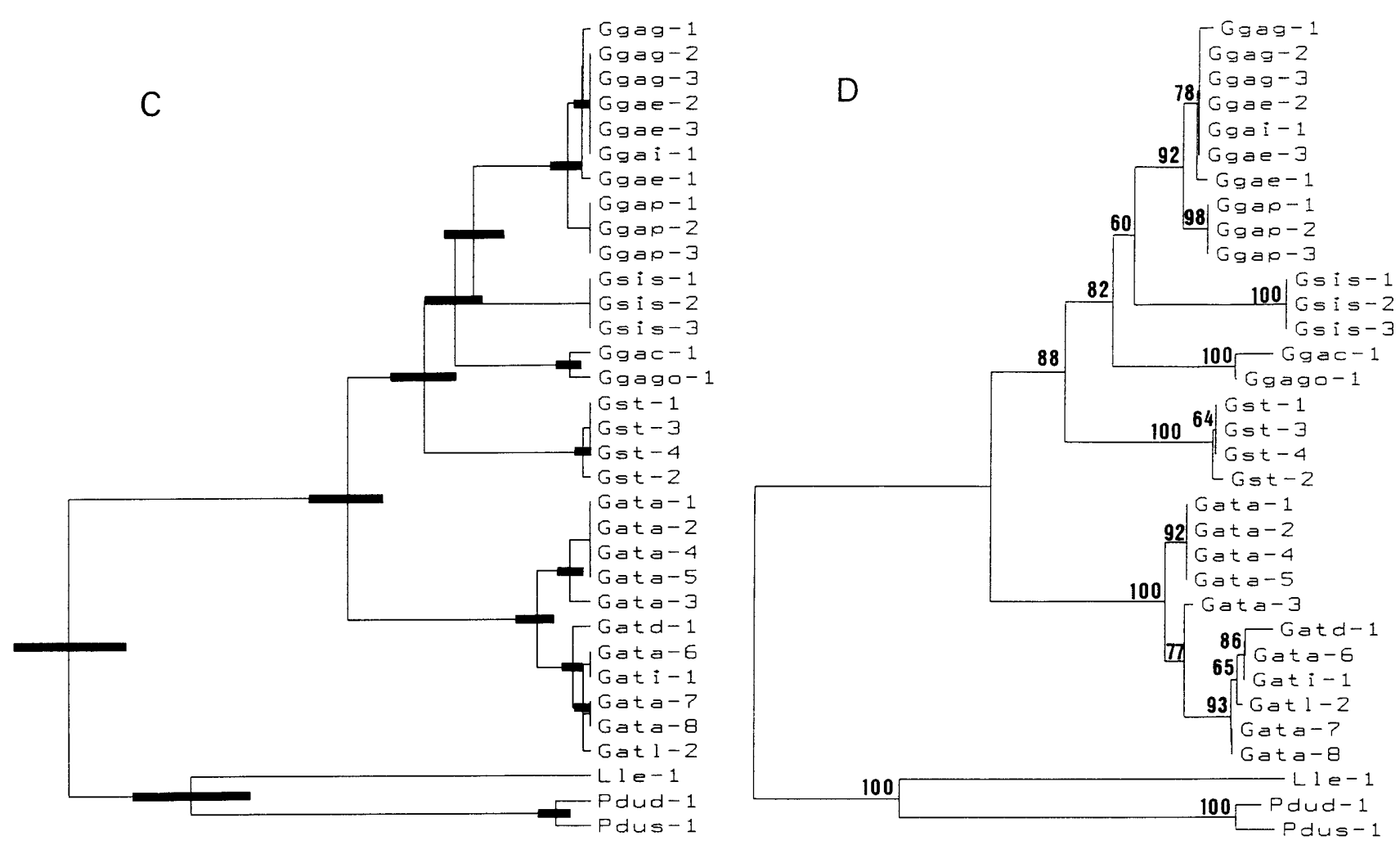

$\theta\ulcorner .01$

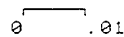

FIG. 5. Relationships among species and subspecies of lizard genus Gallotia, obtained by UPGMA $(A, C)$ and neighbor joining methods $(B, D)$, based on cytb $(A, B)$ and $12 S$ rRNA $(C, D)$ sequences. Numbers on trees indicate the percentage of bootstrapped trees supporting each node. 
lows: G. galloti Z48034 and Z48038; G. atlantica Z48035 and Z48040; G. stehlini Z48036 and Z48039; G. simonyi Z49751 and Z49752; P. dugesii Z48037 and Z48041; and L. Iepida Z48049 and Z48050 for cytb and 12S rRNA, respectively. The collection material analyzed in this paper is at the Zoology Department of La Laguna University.

\section{ACKNO WLEDG MENTS}

We thank A. Martín, A. M. González, and J . M. Larruga for providing hel pful discussions and critical reading of the manuscript, $F$. M. Medina for collecting some of the specimens analyzed in this study, and P. H. Carpio for technical assistance. This work has been supported by Grant PB94-0585 from DGICYT (Spain).

\section{REFERENCES}

Anderson, S., Bankier, A. T., Barrell, B. G., Debruijn, M. H. L., Coulson, A. R., Drouin, J ., Eperon, I. C., Nierlich, D. P., Roe, B. A., Sanger, F., Schreier, P. H., Smith, A. J . H., Staden, R., and Young, I. G. (1981). Sequence and organization of the human mitochondrial genome. Nature 290: 457- 465.

Arnold, E. N. (1973). Relationships of the Palearctic lizards assigned to the genera Lacerta, Algyroides and Psammodromus (Reptilia: Lacertidae). Bull. Br. Mus. Nat. Hist. (Zool.) 25: 289- 366.

Arnold, E. N. (1989). Towards a phylogeny and biogeography of the lacertidae: Relationships within an old-world family of lizards derived from morphology. Bull. Br. Mus. Nat. Hist. (Zool.) 55: 209257.

Barquin, J ., and Martin, A. (1982). Sobre la presencia de Gallotia (= Lacerta) atlantica (Peters y Doria, 1882) en Gran Canaria (Rept., Lacertidae). Doñana Acta Vert. 9: 377- 380.

Bischoff, W. (1982). Die innerartliche Gliederung von Gall otia gall oti (Duméril and Bribon, 1839) (Reptilia: Sauria, Lacertidae) auf Te neriffa, Kanarische Inseln. Bonn. Zool. Beitr. 33: 363- 382.

Bischoff, W. (1985). Vorläufige Beschreibung der Eidechse der Kanareninsel Fuerteventura als Gallotia atlantica mahorataessp. n. (Sauria: Lacertidae). Salamandra 21: 46-54.

Bischoff, W., Osenegg, K., and Mayer, W. (1989). Untersuchungen zur subspezifischen Gliderung der Madeira Mauereidechse, Podarcis dugesii (Milne-Edwards, 1829). Salamandra 25: 237- 259.

Boettger, C. R., and Müller, L. (1914). Preliminary notes on the local races of some canarian lizards. Ann. Mag. Nat. Hist. 14: 67-78.

Böhme, W., and Bings, W. (1975). Zur Frage des Überlebens von Lacerta S. simonyi Steindachner (Sauria: Lacertidae). Salamandra 11: 39-46.

Cano, J ., Baez, M., Lopez-J urado, L. F ., and Ortega, G. (1984). Karyotipe and chromosome structure in the lizard, Gall otia gall oti in the Canary Islands. J . Herpetol. 18: 344- 346.

Castroviejo, J ., Mateo, J . A., and Collado, E. (1985). Sobrela sistemática de Gallotia atlantica (Peters y Doria, 1882). Doñana Acta Vert. Publicación ocasional: 1-85.

F elsenstein, J . (1985). Confidencelimits on phylogenies: An approach using the bootstrap. Evolution 39: 783-791.

Hedges, S. B., Bezy, R. L., and Maxson, L. R. (1991). Phylogenetic relationships and biogeography of xantusiid lizards, inferred from mitochondrial DNA sequences. Mol. Biol. Evol. 8: 767780.
Higgins, D. G., Bleasby, A. J ., and Fuchs, R. (1992). CLUSTAL V: Improved software for multiple sequence alignment. Comput. Appl. Biosci. 8: 189-191.

Howell, N., and Gilbert, K. (1988). Mutational analysis of the mouse mitochondrial cytochrome b gene. J . Mol. Biol. 203: 607-617.

J in, L., and Ferguson, J. W. H. (1990). Neighbor-joining tree and UPGMA tree software, Center for Demographic and Population Genetics, University of Texas, Health Science Center at Houston, Texas 77255.

Kimura, M. (1980). A simple method for estimating evolutionary rate of base substitutions through comparative studies of nucleotide sequences. J . Mol. Evol. 16: 111-120.

Klemer, K. (1976). The Amphibia and Reptilia of the Canary I slands. In "Biogeography and E cology in the Canary I slands. Monographia Biologica 30" (G. Kunkel, Ed.), pp. 433-456, J unk, The Hague.

Kocher, T. D., Thomas, W. K., Meyer, A., Edwards, S. V., Pääbo, S., Villablanca, F. X., and Wilson, A. C. (1989). Dynamics of mitochondrial DNA evolution in animals: amplification and sequencing with conserved primers. Proc. Natl. Acad. Sci. USA 86: 6196-6200.

Kumar, S., Tamura, K., and Nei, M. (1993). MEGA: Molecular evolutionary genetic analysis, version 1.01, Pennsylvania State University, University Park, PA 16802.

Lopez-J urado, L. F., Cano, J ., and Baez, M. (1986). Estudios sobre la herpetofauna canaria I. El cariotipo de Gallotia simonyi stehlini y de G. atlantica spp. en poblaciones de la isla de Gran Canaria. Amphibia-Rept. 7: 259-270.

Machado, A., Lopez-J urado, L. F., and Martin, A. (1985). Conservation status of reptiles in the Canary Islands. Bonn. Zool. Beitr. 36: 585- 606.

Martin, A. (1985). Los lagartos de los roques del norte de Tenerife. Bonn. Zool. Beitr. 36: 517-528.

Mayer, W., and Bischoff, W. (1991). Artbildung auf Inseln: Theorie zur Evolution der Eidechsen der Gattung Gallotia (Reptilia: Lacertidae) anhand albumin-immunologischer Analysen und geologischer Daten zur Entstehungsgeschichte des Kanarischen Archipels. Mitt. Zool. Mus. Berlin 67: 69-79.

Naranjo, J . J ., Nogales, M., and Quilis, V. (1991). Sobre la presencia de Gallotia stehlini en la isla de Fuerteventura (Canarias) y datos preliminares de su alimentación. Rev. Esp. Herp. 6: 45-48.

Nei, M., Stephens, J . C., and Saitou, N. (1985). Methods for computing the standard errors of branching points in an evolutionary tree and their application to molecular data from human and apes. Mol. Biol. Evol. 2: 66-85.

Saitou, N., and Nei, M. (1987). The neighbor-joining method: A new method for reconstructing phylogenetic trees. Mol. Biol. Evol. 4: 406- 425 .

Schenkel, E. (1901). Achter Nachtrag zum Katalog der herpetologischen Sammlung des Basler Museums. Verh. Naturforsch. Ges. Base 13: 142-199.

Sneath, P. H. A., and Sokal, R. R. (1973). "Numerical Taxonomy," Freeman, San Francisco.

Steindachner, F. (1989). Bericht über eine von Prof. O. Simony auf den Roques de Zalmor bei Hierro (Canarische Inseln) entdeckte neueE idechsenart von auffallender gröBe, Lacerta simonyi Steind. Anz. Akad. Wiss. Wien 26: 260-262.

Thorpe, R. S. (1985). Extent of racial divergencein the eastern Canary I sland lizard, Gall otia atlantica. Bonn. Zool. Beitr. 36: 507-512.

Thorpe, R. S., McGregor, D. P., and Cumming, A. M. (1993a). Molecular phylogeny of the Canary I sland lacertids (Gallotia): mitochondrial DNA restriction fragment divergence in relation to sequence divergence and geological time. J . Evol. Biol. 6: 725-735.

Thorpe, R. S., McGregor, D. P., and Cumming, A. M. (1993b). Population evolution of western Canary Island lizards (Gallotia galloti): 
4-base endonuclease restriction fragment length polymorphisms of mitochondrial DNA. Biol. J . Linn. Soc. 49: 219-227.

Thorpe, R. S., McGregor, D. P., Cumming, A. M., and J ordan, W. C. (1994). DNA evolution and colonization sequence of island lizards in relation to geological history: mtDNA RFLP, cytochrome b, cytochrome oxidase, 12s rRNA sequence, and nuclear RAPD analysis. Evolution 48: 230-240.
Thorpe, R. S., Watt, K., and Baez, M. (1985). Some interrelationships of the Canary Island lizards of the genus Gallotia. Bonn. Zool. Beitr. 36: 577-584.

Zhu, D., J amieson, B. G. M., Hugall, A., and Moritz, C. (1994). Sequence evolution and phylogenetic signal in control-region and cytochrome $b$ sequences of Rainbow Fishes (Melanotaeniidae). Mol. Biol. Evol. 11: 672-683. 